\title{
Post-Kolonyalizm ve Leopold Sedar Senghor: Tartışmalı Bir Düşünür Üzerine Bir Inceleme
}

\section{Post-Colonialism and Leopold Sedar Senghor: An Analysis of a Controversial Thinker}

Eray Alım ${ }^{a, *}$

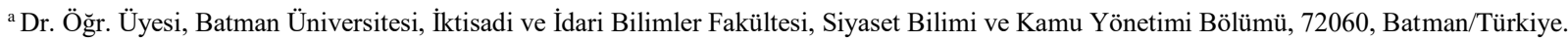
ORCID: 0000-0001-7543-8021

\section{MAKALE BILLGISİ}

\section{Makale Geçmişi:}

Başvuru tarihi: 01 Kasım 2020

Düzeltme tarihi: 20 Ocak 2021

Kabul tarihi: 26 Ocak 2021

\section{Anahtar Kelimeler:}

Post-Kolonyalizm

Léopold Sédar Senghor

Afrika

Senegal

Fransa

\section{A R T I C L E I N F O}

\section{Article history:}

Received 01 November 2020

Received in revised form 20 January 2021

Accepted 26 January 2021

\section{Keywords: \\ Postcolonialism \\ Léopold Sédar Senghor \\ Africa \\ Senegal \\ France}

ÖZ

Bu çalışmada, Post-Kolonyal düşünce dâhilinde Léopold Sédar Senghor'un konumu incelenmiştir. Şair, filozof ve siyasetçi gibi farklı özellikleri bünyesinde barından Senegal'in eski devlet başkanı Senghor, çok boyutlu bir Post-Kolonyalizm analizine imkân tanımaktadır. Bu bağlamda bu çalışma, Senghor'un entelektüel ve siyasetçi kimliklerini mercek altına alarak, bu iki kimlik arasındaki ilişkinin mahiyetini sorgulamaktadır. Sonuç olarak, Senghor'un "Siyahi-Afrikalılık" savunusu etrafında felsefi ve poetik bir başkaldırı ortaya koyduğu; siyasetçi olarak ise Fransa ile geliştirdiği yakın ilişkiler nedeniyle daha pragmatik bir profil arz ettiği saptanmaktadır. İlaveten, Post-Kolonyal dönem ve Soğuk Savaş şartları Senghor'un hareket alanını daraltmışsa da bu ismin sömürge karşıtlığının bayraktarlarından biri olmayı sürdürdüğü sonucuna ulaşılmaktadır.

\section{Giriş}

Post-Kolonyalizm, İkinci Dünya Savaşı'nın ardından yaşanan sömürge sonrası sürecin anlaşılması ve açıklanması için geliştirilmiş bir teorik yaklaşımdır. Fransa ve Büyük Britanya başta olmak üzere Batı ülkelerinin sömürgesi olmaktan kurtulan ulusların durumunu analiz eden bu yaklaşım, tarihle günümüz arasında bir bağ kurarak, sömürgeci geçmişin yarattığı siyasi, ekonomik ve kültürel etkileri incelemeyi amaç edinmiştir. Dünyaya Post-Kolonyal bir mercekten bakanlar, Afrika, Ortadoğu ve Güneydoğu Asya başta olmak üzere üçüncü dünya olarak kabul edilen coğrafyalardaki ülkelerin karşılaştıkları eşitsizlikleri güçlü sorgulamalara tabi tutmuşlardır. $\mathrm{Bu}$ sorgulamanın yapılmasında, belli başlı düşünürler yol gösterici bir işlev görmüştür. Bunlar arasında Edward Said, Franz Fanon,

\footnotetext{
* Sorumlu yazar/Corresponding author.

e-posta: erayalim@hotmail.com
} 
Aime Cesaire, Gayatri C. Spivak gibi isimler yer almaktadır. Léopold Sédar Senghor da Post-Kolonyal ekol dâhilinde köşe taşı mahiyetindeki isimlerden biridir.

Bu çalışmanın üzerinde duracağı isim olan Senghor'u diğer isimlerden ayrıştıran önemli bir husus, bu düşünürün farklı kimlikleri bünyesinde barındıran bir figür olarak siyasi, felsefi ve entelektüel açılardan çok boyutlu bir PostKolonyalizm analizine imkân tanımasıdır. Senghor; şair, filozof, akademisyen, eski bir Fransız askeri ve bağımsız Senegal'in ilk devlet başkanı olarak, 2001'de sonlanan 95 y1llık ömründe farklı özellikleri bünyesinde barındırmış bir siyasetçi ve düşünce insanı olmuştur. Siyahilik (Negritrude) akımının öncü isimlerinden olan Senghor, Afrikalı siyahi bireyin kendine özgü mizacına referansla geliştirdiği perspektifle "Post-Kolonyal Özne'nin" nasıl anlaşılması gerektiği ile ilgili net bir çerçeve ortaya koymuştur. İlerleyen satırlarda açıklanacağı gibi, doğduğu Afrika topraklarının özgül kültürel özelliklerinden hareketle Senghor, Afrikalı bireyi duygularla yoğrulmuş, iç huzura sahip ve doğa ile barışık halde tasvir ederek, adeta poetik bir var oluş hali resmetmiştir.

Senghor, geliştirdiği felsefi tasavvurla Afrika düşünce dünyasında önemli bir isim olmuşsa da İkinci Dünya Savaşı sonrasında siyasete giriş yaparak daha farklı bir kulvarda ilerlemeyi seçmiştir. Bu süre zarfında Senghor, Afrikalı özneyi Batı medeniyetinden ayrıştırmaktansa, kapsayıcı ve hatta kolonyal bir ülke olan Fransa ile eski sömürgelerini bütünleştirici bir tahayyül ortaya koymaya başlamıştır. Ayrıca Senghor, Senegal dâhil Afrika ülkelerinin hızlı bir bağımsızlık süreci içine girmelerine karşı çıkarak, Fransa ile kültürel, siyasi ve ekonomik bağların muhafaza edilmesini savunmuştur. Bu hususlar dikkate alındığında, Senghor'un düşünce insanı ve siyasetçi olarak ortaya koyduğu bakış açıları arasında gözle görülür farklılıklar söz konusudur. Peki Senghor özelinde olduğu gibi, Post-Kolonyal dünyada önemli yere sahip olan düşünürlerin geçirdikleri fikirsel dönüşüm bize ne söylemektedir? Düşünürlerin geçirdikleri dönüşüm ve yaşamlarının farklı evrelerinde edindikleri yeni bakış açıları nasıl analiz edilmelidir? Senghor gibi düşünürler siyaset sahnesine çıtıklarında, entelektüel kimlikleri ile örtüşmeyen söylem ve eylemlerde bulunuyorlarsa, bu durum ne şekilde irdelenmelidir? Bu çalışma, bu gibi sorulara Senghor'u merkeze alarak cevap üretmeye çalışacaktır.

Çalışmada ele alınacağı üzere, çeşitli eleştirilere muhatap olan Senghor'un tartışmalı bir isim olması hasebiyle, felsefi ve siyasi kimliğini esas alan analitik bir yaklaşım üzerinden değerlendirilmesi gerekmektedir. Nitekim bu çalışma siyasi analiz olarak nitelendirebilecek yöntemsel bir bakış açısına sahip olup, bir diskur analizi özelliği taşımamaktadır. Senghor'un söylem ve eserlerinin tamamı Fransızca olduğu için, Fransızca diline hâkim olmayan bu çalışmanın yazarı, bu kaynaklardan yararlanamamıştır. Dolayısıyla, ikincil kaynaklar bu çalışma kapsamında önemli bir yere sahiptir. Buna rağmen, İngilizce çevrilerden yararlanılarak Senghor'un görüşlerine, yeterli olmamakla birlikte, yer verilmektedir. Esas amaçlanan ise gerek birincil kaynaklardan yararlanabilecek gerekse Post-Kolonyal ekole ve daha genel olarak Uluslararası İlişkiler disiplinine ilgi duyan ya da duyabilecek araştırmacılara Senghor'a dair analitik bir tartışma sunabilmektir. Zira Türkiye'de sosyal bilimler alanında çok az bilinen bir isim olan Senghor, gerek bir düşünce insanı gerekse eski bir devlet başkanı olarak daha fazla ilgi görmeyi hak eden bir isimdir.

$\mathrm{Bu}$ bağlamda bu çalışma Post-Kolonyal bir mercekten bakarak, Senghor ile ilgili bir siyasi-felsefi perspektif ortaya koymayı hedeflemektedir. $\mathrm{Bu}$ makale toplamda dört bölümden oluşmaktadır. İlk olarak çalışmanın teorik ve ampirik bağlamını oluşturan Fransa-Batı Afrika/Senegal ilişkileri, Post-Kolonyal bir çerçevede irdelenmektedir. İkinci bölümde ise, Senghor'un erken dönemi olarak tanımlayabileceğimiz 1928-1940 arasındaki dönem, bu düşünürün felsefi-düşünsel yaşamına odaklanılarak incelenmektedir. Ardından, İkinci Dünya Savaş'ından sonra Senghor'un siyasi alana giriş yapması ve bu süreçte geçirdiği fikirsel dönüşüm analiz edilmektedir. Son olaraksa Senghor'un dekolonizasyon ve Soğuk Savaş dönemine denk gelen devlet başkanlığı sürecinde uluslararası arenada yaşanan gelişmelere dönük nasıl bir tavır aldığı masaya yatırılmaktadir.

\section{Fransa, Afrika ve Post-Kolonyal Döneme Varış: Tarihsel ve Kavramsal bir Arka Plan}

Tarihsel bağlamda Fransa, Büyük Britanya ile birlikte, Batı Afrika'da varlık tesis etmiş olan iki temel sömürge gücünden biridir (Chafer, 2002: 2-3). Fransa'nın sömürge politikasına yön veren başlıca yaklaşımlardan biri ise asimilasyon politikası olmuştur (Morgenthau, 2008: 617-618). Bu politika, Jean-Jacques Rousseau'nun ortaya koyduğu ve Fransız İhtilali'nin savunduğu "bütün insanların eşitliği" ilkesine dayanmıştır. Nitekim 1794 tarihinde, Toussaint L'Ouverture liderliğinde Haiti'deki siyahi kölelerin isyanlarının ardından Jakobenlerin aldığı kararla köleliğin kaldırılması, devrim atmosferinin ürünü olan kritik gelişme olarak kayda geçmiştir. Devrim liderlerinden Maximilien Robespierre'in vurguladığı gibi bu olay, Büyük Britanya karşısında Fransa'ya moral üstünlük kazandırmış ve özgürlük meşalesinin artık Fransa tarafından taşındığını göstermiştir. İnsan eşitliği ilkesinden hareketle devrim liderleri, her ne kadar küçük bir nüfusa karşılık gelmişse de, Fransız sömürgelerine Fransız vatandaşlığı hakkı tanıyarak eşitlik prensibini uygulamaya başlamışlardır (Morgenthau, 2008: 617-618; Losurdo, 2011: 137; Young, 2016: 30).

Fransız İhtilali özelinde müşahede edildiği gibi, hürriyet ve eşitlik talepleri üzerine temellenen sömürge karşıtlığı ve bağımsızlık şiarı güçlü bir zemin bulmuştur. Haiti örneğinde belirgin bir şekilde görüldüğü üzere, L'Ouverture'ün liderliğinde 1804 'te bağımsızlığını kazanan bu ülke, Hispanyola adasında İspanya'nın kontrol ettiği tarafta bulunan kölelerin de bir bölümünü esaretten kurtarmış; ayrıca özgürlük mücadelelerinde Küba'daki siyahilerle ilham kaynağı olmuştur (Losurdo, 2011: 152). Fransız İhtilali'nin yansımaları tekil hadiselerle sınırlı kalmayarak, daha kalıcı etkiler de yaratmıştır. Örneğin yaşanan ihtilal, teritoryal devlet kurma fikrinin, egemenlik kavramının ve esas önemlisi, milliyetçilik ideolojisinin zemin bulmasını sağlamıştır (Rowe, 2013: 143-145). Fransa özelinde bakıldığında, ihtilalin beraberinde getirdiği normatif devrim ve dönüşüm, bu ülkenin dış siyasetini yalnızca geçici bir süreliğine karakterize etmiştir. Zira devrim sonrasında Napolyon Bonaparte'ın istilacı politikasında somutlaştığı gibi, Fransız İhtilali'nin ürünü olan özgürlük ve eşitlik gibi ilkeler kısa süre içinde bir tarafa bırakılmış ve emperyal politikalara devam edilmiştir (Hobsbawm, 1996: 77-78). Bu 
politikalar uygulanırken, yerli halkları uygarlık seviyesine çıkarma sorumluluğu önemli bir gerekçe olmuştur. 17981799 Misır Seferi, uygarlik misyonunu yerine getirme sorumluluğunun ilk uygulamasını teşkil etmiş ve müteakiben bu düşünce, 19. yüzyıl Fransız emperyalistlerine ilham kaynağı olmuştur. Cezayir'in Fransız sömürgesi haline getirilmesi sürecinde ise uygarlık misyonu, Fransız lügatine tam teşekküllü bir şekilde giriş yapmıştır (Sessions, 2011: 6).

Uygarlık misyonu fikrinden hareketle farklı ulusları asimile etme politikası, Fransız değerlerinin üstünlüğü inancına dayanmıştır. Said'in belirttiği gibi, Fransız İmparatorluğu'nun varsayılan üstünlüğü, Fransa'nın ulusal kimliğine, medeniyet enerjisine, müstesna coğrafi, sosyal ve tarihsel özelliklerine dayanmaktaydı. Her ne kadar Cezayir, Gabon ve Madagaskar gibi sömürgelerde yerlilerin yaşadıkları hayat, yücelik fikrine tezat bir görüntü arz etmişse de entelektüel ve lobi çevrelerinde Fransız üstünlüğü fikri hâkimdi (Said, 1993: 170-171). Öte yandan, ilk adımı Cezayir istilası ile atılan Afrika'ya girme süreci, uygarlık misyonunu yerine getirmek kadar, jeopolitik gerekliliklerin de bir sonucuydu. Zira Osmanlı İmparatorluğu'nun gerilemekte olduğu bir süreçte Fransa, Mağrip bölgesinde varlık tesis ederek rakibi Büyük Britanya'ya karşı Akdeniz jeopolitiğinde avantaj elde etmeyi hedeflemişti. Bununla birlikte, Cezayir'i ele geçirerek ve burayı bir "sıçrama tahtası" olarak kullanarak Sahra-Altı Afrika’ya giriş yapmak da Fransa'nın hedefleri arasında yer almıştı (Sessions, 2011: 7).

Fransa, 19. yüzyılda Sahra-Altı Afrika'da hâkimiyet arayışını icra ederken, Batı Afrika bölgesi sömürge politikasının ağırlık noktasını teşkil etmiştir. Bu bölgede 1851-1894 arasında sırasıyla Dahomey, Senegal, Fildişi Sahili ve Fransız Ginesi, Fransa'nın sömürgeleri arasına katılmıştır (France in West Africa). Fransa'nın sömürge politikası zamanla sistematik bir hal kazanmıştır. Afrika'nın parsellenmesi olarak tanımlanabilecek bir minvalde Fransa, Büyük Britanya ve Almanya gibi Avrupalı güçler, Afrika kıtasında sömürge alanları ve bu alanları yönetecek idari birimler kurmuşlardır. Batı Afrika özelinde bakıldığında, Almanya'nın kontrolünde olan ve Birinci Dünya Savaşı'ndan sonra Fransa'nın eline geçen Togo hariç, Fransız Batı Afrika'sı olarak bilenen topraklar ya işgal ya da anlaşma yoluyla Fransa'nın eline geçmiştir. Büyük Britanya'nın Batı Afrika'da birbirinden kopuk şekilde var olan sömürgelerinden farklı olarak Fransa'nın sömürge toprakları bir bütünlük arz etmiş ve 1895 'ten sonra bu topraklar tek bir idari birim altında yönetilmiştir (Okoth, 2006: 314).

Fransa'nın Batı Afrika dâhil Afrika kıtasının muhtelif bölgelerinde kurduğu sömürge düzeni, İkinci Dünya Savaşı'nın sonrasına kadar devam etmiştir. 20. yüzyılın ikinci yarısından itibaren ivme kazanmaya başlayan dekolonizasyon süreci ise 1960 yılında Senegal, Dahomey ve Fildişi Sahili'nin bağımsızlıklarını kazanmasına vesile olmuştur (France in West Africa). Sahra-Altı Afrika'sında görece sakin bir şekilde gerçekleşen bağımsızlık sürecinden farklı olarak, Kuzey Afrika'da bir diğer Fransız sömürgesi olan Cezayir'de ciddi bir silahlı çatışma süreci yaşanmıştır (Kras, 1999). Ulusal Kurtuluş Cephesi'nin (FLN) 1954'te başlamasına öncülük ettiği ulusal isyan ile Cezayirli direnişçiler; sabotaj ve silahlı mücadele yöntemleri de kullanarak, Fransız güçlerine karşı bağımsızlık mücadelesine girişmişlerdir (Evans, 2012: 123). Sekiz senelik bu zorlu mücadele sonunda Cezayir, Batı Afrika ülkelerinden iki yıl sonra, 1962'de bağımsızlığına kavuşmuştur.

İkinci Dünya Savaşı'nı takiben sömürge düzeninden sömürge sonrası düzene geçiş süreci, Post-Kolonyal ekolün temel inceleme konusu olmuştur. Bu ekol, Avrupa sömürge güçlerinin toprakları dişındaki halklar üzerinde kurdukları tahakküm ve bu tahakkümün günümüz dünyasındaki yansımalarının bir analizini gerçekleştirmiştir. PostKolonyal ekole ilham veren W. E. B. Du Bois ve Franz Fanon gibi isimler, öncelikle sömürge güçlerinin üçüncü dünya halkları üzerinde yarattığı psikolojik tahribata odaklanmışlar, daha sonra ise eşitlik ve self-determinasyon vurguları üzerinden siyasi özgürleşmenin önemine dikkat çekmişlerdir (Young, 2016: 221). Post-Kolonyal düşünce dahilinde köşe taşı mahiyetinde bir isim olan Fanon, yerlilerin sömürge düzenine son vermesinin ve tam manasıyla özgürleşmesinin yolunun güç kullanmaktan geçtiğini vurgulamıştır. Bunu, bir nevi, "meditasyon” olarak tanımlayan Fanon, sömürgeleştirilmiş öznenin "şiddet içinde ve şiddet yoluyla" özgürleşeceğini iddia etmiştir (Fanon, 2004: 44). Fanon'un tasavvurunda şiddet yoluyla psikolojik rehabilitasyon bir boyut teşkil etmişmişse de ezilenlerin ulusal özgürlüklerine kavuşması, verilen mücadele bağlamında asıl vurgulanan nokta olmuştur. Bu bağlamda, Dien Bien Phu'da Vietnamlı savaşçıların Fransız güçlerine karş1 ortaya koydukları silahlı direnişi hatırlatan Fanon, sömürge güçlerine karşı girişilen mücadelenin bütün ezilen halklar için bir cesaret kaynağı olduğunu belirtmiştir (Fanon, 2004: 30-31).

Fanon'un başarmaya çalıştığı gibi, geçmişten mevcut döneme kadar süregelen tahakküm ilişkilerini görünür kılmak, Post-Kolonyal yaklaşımın ulaşmaya çalıştığı başlıca hedef olmuştur. $\mathrm{Bu}$ hedefe matuf olarak Post-Kolonyal dönemin önemli siyasetçi ve aydın figürleri, gerektiğinde Batı'da elde ettikleri entelektüel araçlarla Batı hegemonyasını yıkmaya ve kendi siyasi hedeflerine ulaşmaya çalışmışlardır. Cabral, Fanon, Ho Chi Minh, Kenyatta, Nkrumah ve Senghor gibi birçok sömürge karşıtı düşünür, Batı'da eğitim almışlar ve Marksizm ve Sosyalizm gibi ideolojilerle Batı şehirlerinde tanışmışlardır. Daha sonra devlet başkanlığı dâhil siyasette muhtelif pozisyonlara gelen bu isimler, Batı'da tanıştıkları ideolojik akımları kendi siyasi programları çerçevesinde uygulamaya çalışmışlardır (Young, 2016: 68).

İçinde barındırdığı güçlü normatif boyutla Post-Kolonyal ekol ise, geçmişin unutulmaması ve sömürge düzeniyle yüzleşilmesi talepleri üzerinden Batı-merkezli anlatılara dönük etkili bir itiraz ortaya koymuştur (Dirlik, 1998; Spivak, 2010; Krishna, 2001; Darby, 2004). Post-Kolonyal dönemde Küresel Güney'deki aktörlerle gelişmiş Batı ülkeleri arasında meydana gelen ihtilafları anlamlandırma denemesinde, arka plandaki baskıcı ve eşitliksiz ilişkilerin bir faktör olarak önemi hatırlatılmıştır. $\mathrm{Bu}$ hatırlatma çabalarında, Edward Said'in Şarkiyatçılık kitabında Fransız düşünür Michel Foucault referanslı olarak bilgi-tahakküm ilişkisine yaptığı vurgu, merkezi bir öneme sahip olmuştur (Said, 2003). Şark olarak nitelenen bölgenin, Avrupa'nın imgelemesinden ibaret olduğunu edebiyat eserlerine atıfla açıklayan Said, daha yakın dönemde ise Batı menşeli entelektüel ve akademik kurumların İslam, Şark ve Arapları klişeleştirme çabalarına dikkat çekmiştir (Said, 2003: 301 302). Bilgi-tahakküm ilişkisine Post-Kolonyal bir açıdan 
bakıldığında, Batı'nın üçüncü dünya üzerinde oluşturmak istediği epistemolojik hükümranlığın, geçmiş ve günümüz hakkında "anlatı hegemonyası" kurma amacına matuf olduğu ortaya çıkmaktadır. Bunun en belirgin şekilde görüldüğü alanlardan biri ise Uluslararası İlişkiler disiplinidir (Smith, 2000). Bu durum karşısında PostKolonyal ekol, hâkim anlatılara karşı çıkmayı ve sömürge geçmişini merkeze alarak küresel siyasete dair bir perspektif sunmayı amaç edinmiştir. Post-kolonyal öznenin merceğinden geçmişe dair bir muhasebe yapıldığında vurgulanan temel husus, eşitsizlik ve tahakküm üzerine kurulu sömürge düzeninin, günümüzdeki hiyerarşik ilişkilerin devamında da kritik bir rol oynadığıdır (Laffey vd., 2008). Post-Kolonyalizm bu gerçekliği, üçüncü dünyanın kendi anlatısını merkeze alarak dile getirmektedir. Sartre'ın Fanon'a atıfla vurguladığı gibi, esas amaçlanan, "Üçüncü Dünya'nın kendisini keşfetmesi" ve kendi sesi üzerinden muhataplarına hitap etmesidir (Sartre, 2004: xlvi).

$\mathrm{Bu}$ hitabın gerçekleşmesi için, Said'in merceğinden bakıldığında, Şark'ın da içinde yer aldığı Üçüncü Dünya olarak tarif edilen bölgenin Batı'nın simgeleştirdiği bir temsil olmaktan kurtulması zaruridir. Said, Avrupa medeniyetinin maddi ve kültürel gelişiminde Şark gibi Batı dışındaki coğrafyaların içkin birer yere sahip olduklarını kaydederken, çeperdeki bölgelerin destekleyici kurumlar, kelimeler, imgeler, doktrinler ve hatta kolonyal bürokrasiler ve yöntemlerle istenen biçime sokulduklarını vurgulamaktadır (Said, 2003: 2). Said kitabında Bernard Lewis gibi tarihçiler üzerinden Şark'ın temsil edilme şekline dair güçlü eleştiriler dile getirmiş ve bunun akabinde kendisi de karşı eleştirilere maruz kalmıştır (Lewis, 1982). Her ne kadar Said'in eleştirdiği isimlerin tepkisini üzerine çekmesi normalse de farklı isimler de kendisinin bakış açısında belirli eksik ve noksan taraflar olduğunu kaydetmiştir. Bunlardan biri, Suriyeli düşünür Sadık Al-Azm olmuş ve kendisi “Tersinden Şarkiyatçılık” olarak isimlendirdiği eleştirel bir yaklaşım üzerinden Said'in çalışmasını sorgulamıştır.

Al-Azm'a göre Said, Batı'nın Doğu üzerinde kurduğu tahakkümü irdelerken, özcü bir yaklaşıma sürüklenmiştir. Her ne kadar Said, Batı-Doğu ikiliğinin nasıl simgesel/temsili bir tasvire dayandığını izah etmeyi amaç edinmişse de kendisi de bu ikiliğin üretilmesine katkı sunmuştur. Zira eleştirel bir mercekten de olsa Said, Şark ve Garp (ya da Doğu ve Batı) arasında ontolojik bir ayrım olduğunu varsaymıştır (Al-Azm, 2000: 219). Aşağıda ele alınacağı gibi Senghor gibi düşünürler de ontolojik ayrım fikrine iştirak ettikleri için Said'in bakış açısı bir istisna teşkil etmemektedir. Diğer taraftan, Senghor özelinde açıklanacağı gibi, medeniyetler arasında var olduğu iddia edilen ayrım fikri savunusu bir devamlılık arz etmemiştir.

Al-Azm'ın getirdiği ikinci eleştiri ise Said'in imgeler, kelimeler, söylemler ve temsili tasvirlere "ham gerçekliğin" kendisinden daha fazla önem vermiş olmasıdır. Bu tespitten hareketle Al-Azm, Said'in perspektifinde bir "bilim karşıtlığı" olduğunu vurgulayarak şunu iddia etmiştir: Said'e göre, özellikle "Kültürel-Akademik Şarkiyatçılık” gerçekliği çarpıtan bir rol oynamakta ve Batı'daki çalışmalar Üçüncü Dünya'daki bireylerin öz benliğini yanıltıcı bir biçimde tasvir etmektedir (Al-Azm, 2000: 219). Öte yandan, Timothy Mitchell başta olmak üzere, bizzat Edward Said'in kendisinden etkilenip Şarkiyatçılık karşıtı noktada olan eleştirel düşünürlerin varlığı göz önüne alındığında, Al-
Azm'ın eleştirilerinde bir haklılık payı olduğu görülmektedir (Örnek olarak bkz, Mitchell, 2002).

Bununla birlikte, gerçekten de Doğu-Batı ya da KuzeyGüney ekseninde yaşanan etkileşimler Said'in varsaydığından çok daha dinamik bir tablo arz etmiştir. Bu husus çerçevesinde Post-Kolonyal ekol dahilinde Said ile ilgili dile getirilebilecek bir diğer eleştiri, Üçüncü Dünya'daki özenenin Said tarafından pasif bir özne olarak mütalaa edilmesidir (Barkawi, 2008; Adib-Moghaddam, 2011). Bu mütalaa, Barkawi’nin vurguladığı gibi, Batı merkezli hegemonik yapının direnişlerle ve karşı meydan okumalarla karşılaştığının görülmemesi gibi bir soruna neden olmuştur. Buna karşın Küresel Güney'de, bu çalışmada Senghor ve Siyahilik Ekolü özelinde irdeleneceği gibi, "isyankar bir bilinç" şekillenmiş ve vücut bulmuştur. Yukarıda zikredildiği gibi, L'Ouverture'un gerek siyahilerin özgürleşmesine önderlik etmesi gerekse farklı kitleleri etkileyebilmesi, bu durumu gözler önüne seren bir örnek olmuştur (Barkawi, 2008: 8).

Al-Azm'ın eleştirisi, Barkawi’nin eleştirisi ile birleştirildiğinde görülecektir ki, Said kendi uzmanlığı olan edebiyat ve kültürel çalışmalar alanının sınırlarında kalarak, söylemsel, temsili ve imgesel tahakküme aşırı önem vermiş ve fiziksel mücadele ve direnişin önemini gözden kaçırmıştır (Barkawi, 2008: 8). Bununla birlikte, Küresel Güney'de yer alan bireyin entelektüel anlamda sahip olduğu öznellik, farkındalık ve direniş kapasitesi de gözden kaçmıştır. AdibMoghaddam bu hususu bir örnekle şu şekilde açıklamaktadır: Mısır, Britanya'nın kontrolündeyken, İngiliz Savaş Bakanı Lord Harrington Misırlı entelektüel Muhammad Abduh'a Türklerin hakimiyetinden sonra Mısır'ın Britanya'nın kontrolüne girmesiyle her şeyin artık daha iyi olduğunu fikrine katılıp katılmadığını sormuştur. Abduh ise kendisine "Kesinlikle hayır" diyerek karşılık verip, yabancı bir 1rka ve dine ait bir ulusun tahakkümüne aslı razı olmayacaklarını dile getirmiştir (Adib-Moghaddam, 2011: 103).

Yerelde ortaya konulan gerek fiziksel gerekse entelektüel direniş, Küresel Güney ve Batı arasındaki ilişkinin çok daha karmaşık bir boyuta sahip olduğunu göstermektedir. İlişkilerin tek taraflı ve statik değil, dinamik ve hareketli olduğu kaydedilmelidir. O derece ki, yaşanan süreçlerin dinamik doğası; bakış açılarında, hassasiyetlerde, felsefi ve siyasi tasavvurlarda ciddi değişimleri beraberinde getirmiştir. Senghor'un bize göstereceği gibi, Üçüncü Dünya'da belli entelektüellerin, "şartların gereği” olarak Küresel Güney’deki bağımsızlık hareketlerine mesafeli durmaları, bu bağlamda önemli bir örnektir. Fransa gibi eski sömürgeci ülkelerde ise, Sartre gibi bağımsızlık taraftarı güçlü muhalif isimler var olmuşsa da, Albert Camus gibi farklı bir noktadan olaya bakanlar da olmuştur. Said ise bu isimlere güçlü eleştiriler yöneltmekten sakınmamıştır (Said, 1993: 169-185). Bu bağlamda, yelpazenin her iki tarafında da bir çeşitlilik söz konusudur.

$\mathrm{Bu}$ hususlar bir bütünlük içinde ele alındığında şu görülmektedir ki, Post-Kolonyal döneme gerek varılmadan önce gerekse varıldıktan sonra ortaya çıkan resim, ilk göründüğünden daha fazla katmana sahiptir. Bunun için, süreçlerin dikkatli bir şekilde tahlil edilmesi, tarihsel konjonktürlerin içkin özelliklerinin gözden kaçırılmaması büyük önem taşımaktadır. Zira Batı ve Küresel Güney'deki (veya Doğu'daki) ulus ve kültürler arasında önemli 
farklılıklar olmasına rağmen, Şark-Garp ya da Kuzey-Güney ayrımına indirgenemeyecek yakınlıklar da söz konusu olmuştur. Bu bağlamda, iki taraf arasındaki ilişkilerin ana hattı Küresel Güney'in sömürgeci/emperyal güçlere karşı verdikleri mücadele ve direniş olummuşsa da iki tarafin birbiriyle karşılaşması, geçişkenlikler ve etkileşimleri de beraberinde getirmiştir. Bu çalışmada ele alınacağı gibi, Senghor ve kendisinin etkilendiği Rene Maran gibi isimler, bu etkileşimleri gözler önüne sermiştir.

Her halükârda, Küresel Güney’deki öznenin temel mücadelesi, kendi öz benliği ve kendi var oluşunu kanıtlamak olmuştur. Bunun yolu, her zaman Batı ile keskin bir ayrışma yaşamak anlamına gelmese de, gerek felsefi/entelektüel gerekse politik alanda, Post-Kolonyal özenin görünürlüğünün ve özgüllüğünün tescillenmesidir. Cesaire'ın bir şiirinde "hiçbir ırkın güzelliğin, zekanın, gücün tekelini elinde bulundurmadığı ve Zafer Randevusu'nda herkes için bir yer olduğu" sözü bu bakış açsını yansıtmaktadır (Cesaire, 1969: 85). İlerleyen satırlarda, bu bakış açısının Senghor tarafından ifade edilme şekli ele alınmaktadır.

\section{Felsefi-Düşünsel Alanda Senghor}

Post-Kolonyal düşünce dahilinde önemli bir figür olan Léopold Sédar Senghor (1906-2001), Fransız Batı Afrikası olarak bilinen bölgede ve şimdiki Senegal'in sınırları içinde yer alan Joal'de dünyaya geldi. Zengin bir tüccarın oğlu olan Senghor, annesinin yönlendirmesiyle rahiplik eğitimi almaya başladiysa da bu tercihin kendisi için uygun olmadığını fark ederek başkent Dakar'da eğitimine devam etti. Başarılı performansı sayesinde Fransa' da eğitim görmek için burs kazanan Senghor, 1928 yılında üniversite eğitimi için Fransa'ya yerleşti. Bu süre zarfinda Lycée Louis-leGrand ve Sorbonne'de eğitim gördü. 1935 yılında Fransızca öğretmenliği yapma ehliyetine sahip olan Senghor, önce Tours'ta ögrretmen olarak görev yaptı; ilerleyen dönemde ise Yurt dişı Fransa Ulusal Okulu'nda (École Nationale de la France d'Outre-Mer) Afrika Dilleri ve Medeniyeti alanında profesör olarak çalışmaya başladı (The Editors of Encyclopaedia Britannica, 2019; Vaillant, 1976: 155). Gençlik yıllarında Senghor'un üzerinde Fransız etkisi yoğun bir şekilde hissedilmekteydi. Senghor o yıllardaki hedefini şu şekilde dile getirmişti: "Amacımız sömürgecilerin adeta bir karbon kopyası olmakt1: 'Siyah tenli Fransızlar'. 'Afrikalıların 'beyaz Tanrı'nın parmaklarında yumuşak balmumu' olması ve Fransız kültürünün limanında kurtuluş arayışı içinde olmaları umulmuştu" (Skurnik, 1965: 350).

Fransa'daki eğitim süresi sırasında Senghor, seçkin Fransız öğrencilerle tanışma imkânı buldu. "Fransız üstünlüğünün" nasıl içselleştirildiğini, Fransız kültür ve medeniyetinin ne denli asimilasyon pratiklerine dayandığını Paris'te bulunduğu entelektüel ortamlarda gözlemleyen Senghor, evvelki yıllarda Fransız kültürüne duyduğu yakınlığı revize etmeye başlamıştı. Afrikalı öznenin, Fransız kültür ve medeniyet havzasında yok sayıldığını müşahede eden Senghor, Afrikalının Fransız demek olmadığı, eğitim ve kültür alanındaki Fransız etkisine rağmen, Afrika ile mündemiç bir medeniyetin olduğu yönünde bir sonuca ulaşmıştı. $\mathrm{Bu}$ tecrübeler sonucunda Senghor, kendi yerel kültürünün varlığını ayakta tutma konusunda harekete geçmişti (Vaillant, 1976: 155; Skurnik, 1965: 350). Bu hareketlenmenin önemli adımlarından biri ise Siyahilik (Negritude) akımının ortaya çıkışı olmuştu.

Senghor'un temsilcilerinden biri olduğu Siyahilik ekolü, Senghor, Aimé Césaire ve Léon Damas gibi Afrika ve Karayipler'den Fransa'ya gelen bir grup siyahi entelektüelin bir araya gelmesiyle ortaya çıkmıştır. Organizasyonel bir yapıya sahip olmayan ve daha ziyade entelektüel bir akım olarak bilinen Siyahilik ekolü, sömürge dönemiyle hesaplaşılması, siyahi bireyin Avrupa medeniyeti ile karşılaşma tecrübesinin anlaşılması ve kendine has bir kolektif kimlik sahibi olması gibi konular üzerine eğilmiştir (Jacques, 2011: 4). Bu ekol, siyahi ırkın sömürge döneminde nasıl baskılandığı ve uzun yıllar boyunca adeta bir yabancılaşma sendromu ile yaşamak zorunda kaldığı tespitinden hareketle, bu ırkın sömürge dönemine bir reaksiyon olarak kendi manevi değerlerini esas alan bir var oluş haline ulaşması gerektiğini savunmuştur (Sartre, 1988: 306-307). Bu manevi değerlere ulaşılması ise Afrika kültürünün sömürge öncesi dönemdeki köklerine uzanmasını gerekli kılmıştır (Thompson, 2002: 144). Bu bağlamda, siyasi olduğu kadar, kültürel bağımsızlığın da önemine dikkat çeken Siyahilik hareketi, Batı hakimiyetinin Afrikalı özne üzerinde yarattığı sosyal ve psikolojik etkileri mercek altına almış ve geçmişle kapsamlı bir yüzleşmenin gerekli olduğunu inanmıştır (Irele, 1965: 322). Bu yüzleşme, köleliğin devamını savunan Avrupalılara ve sömürge geçmişinin müsebbibi olan uluslara yönelik bir tepkiyi kapsamak kadar, Afrikalılara dair bir gelecek tasavvuru geliştirmeyi de içermiştir (Mortimer, 2004: 539). Nihai kertede, siyahi bireyin yaşamını tanımlayacak bir kolektif kimliğin inşasının mümkün olduğu vurgulanmıştır.

Siyahilik ekolünün merkezi isimlerinden biri olan Senghor ise, Afrikalı özneyi tanımlarken adeta poetik bir var oluş tasavvuru ortaya koymuştur. $\mathrm{Bu}$ tasavvur çerçevesinde Afrika ve Batı medeniyetlerinin felsefi arka planlarında önemli farklılıkların bulunduğu vurgulanmıştır. Analitik kolaylık için "Avrupalı özne" olarak tanımlanabilecek Batı'daki bireyin, doğayı kontrol edebilmek için geliştirdiği faydac1/işlevsel mantıktan farklı olarak "Afrikalı siyahi özne", doğaya üstünlük kurmak değil, onunla birleşmek ve kaynaşmak yönünde bir yaşam anlayışına sahiptir (Wilder, 2015b: 51). Senghor'un spritüel ve yüzü doğaya dönük Afrika öznesi üzerinden Batı'ya dönük ortaya koyduğu eleştirel yaklaşım, Batılı filozoflardan bazılarının fikirleri ile güçlü paralellikler arz etmektedir. Örneğin Heidegger'in vurguladığ1 gibi, bilimsel mantıkla bezenmiş insan, araştırmak ve incelemek gibi eylemlerle aslında doğayı hapseder ve onu hesaplanabilir bir suret haline getirir (Heidegger, 1977: 19-21). Heidegger'in bilim ve teknikten yararlanan insanın doğayı zapt-u rapt altına almak ve niceliksellikle tanımlanabilen (hesaplanabilen) subjeler yaratmak yönünde geliştirdiği eğilime dair yaptığı vurgu (Heidegger, 1977), Senghor'un Avrupalı özneyi tanımlayışı ile benzerlik göstermektedir. Senghor'un ifadesiyle; "Avrupalı birey nesneyi tanıyabilmek için, onu her zaman kendisinden ayrıştırdı. Onu kendisinden uzak tuttu. Şunu eklemeliyim ki pratik anlamda nesneyi kullanılabilir hale getirmek için onu analizlerinde sabitledi ve onu adeta ölü bir hale getirdi" (Jones, 2010: 144). Buna karşın, Senghor'cu bir açıdan siyahi birey, doğa ile adeta onunla bir aşk yaşar gibi ilişki kuran bir özellik taşımaktadır (Sartre, 1988: 318-317).

Batı'daki eleştirel düşünürlerin "enstrümantal zekâ" olarak tanımladıkları Batı Aydınlanması'nın ürünü olan temel bir 
yaşam pratiği ile (Adorno vd., 2002), Afrikalı siyasi öznenin "sezgisel mantıkla" şekillenmiş yaşam pratiği arasında güçlü farklar vardır (Wilder, 2015b: 51; Donna, 2010: 142). Enstrümantal zeka, gücünü görme yetisinden alır; gördüğünü kontrol etmek ister; buna karşın, Senghorcu bir açıdan sezgisel mantığa sahip Afrikalı siyahi öznenin temel yeteneği görmek değil "dokunmaktır"; bu özne, dokunduğunu kucaklamak, kuşatmak ve onunla bütünleşmek ister (Irele, 1965: 343; Wilder, 2015b: 51). Senghor'un vurguladığı gibi; "Siyahi-Afrikalı kendisini nesneden ayırmaz, onu kendisinden uzak tutmaz, onu gözlemlemez, analiz etmez. Daha net bir ifadeyle, nesneye belirli bir mesafede kaldıktan sonra . . . öldürmeden ya da gözünü dikemeden, onu hayatta tutar. Ona dokunur ve onu hisseder. Zenci-Afrikalı adeta duyguların bir tarlasıdır" (Skurnik, 1965: 351-352). Senghor'un bu değerlendirmesinden çıkarılabileceği gibi, Afrikalı öznenin yaşam tasavvurunda Kartezyen düşüncede bulunan öznenesne ayrımı ve dual/ikili yapılar yoktur. Çünkü Afrikalı özne yaşamı bir bütünlük içinde tasavvur eder, bütün canl1cansız varlıklar arasında metafizik bir bağ olduğunu varsayar ve herhangi bir nesneye zarar vermenin, yaşama şekil veren bütünlüğe zarar vereceğini düşünür. $\mathrm{Bu}$ minvalde özne ve nesne, yaşam ve ölüm, insan ve doğa arasında bir ahenk vardır. Bu tasavvurda Afrikalı özne, yaşamı işlevsel bir mantıkla değil, sezgisel yetenekleriyle kavrar (Jones, 2010: 133, 139, 143-146).

Bütün bu felsefi tahlillerde, Afrikalı bireyin sürgün edilmiş bir özne olduğu ve sömürge tecrübesinden siyahilik bilincini geliştirerek kurulabileceği vurgusu ön plandadır (Jacques, 2010: 8). Bu bakış açısı, Post-Kolonyalizm'in bir karşı çıkış olarak ortaya çıkmasında Senghor'un merkezi önemini gözler önüne sermektedir. $\mathrm{Bu}$ husus açılacak olursa, Senghor'un başlıca isimlerinden biri olduğu Afrika felsefi akımında "zahmet çekme" eylemi merkezi önemdedir. Bu bağlamda Batı felsefesinde "merak" nasıl önemli bir çıkış noktası olmuşsa, kendi medeniyetlerinin kültürel ve siyasi olarak tahakküm altına almaya çalışan Avrupa'ya karşı Senghor, Cesaire ve Nkrumah gibi isimler "zahmet" kavramından hareketle bir çıkış noktası yakalamışlardır (Agada, 2018). Siyahi bireyin yaşadığı tarihsel acıları esas alan bir perspektiften Senghor'un da içinde yer aldığı düşünürler, adeta bir başkaldırı olarak felsefeye sarılmışlardır. Bu başkaldırı ile Avrupalı sömürge güçleri hedef alınmışsa da Senghor ve Siyahilik ekolünün çalışmalarında asıl merkezi özne, siyahi ırkın kendi mensupları olmuştur. Sartre bunu, siyahiler arası bir diyalog olarak tarif etmektedir. Kendisinin vurguladığı gibi, "bu siyahiler siyahilere siyahilerin durumuyla ilgili hitap etmekteler" ve yazdıkları şiirlerle esas itibariyle "bir bilinç uyanmasına" vesile olmaya çalışmaktalar (Sartre, 1988: 293).

\section{Siyasi Arenada Senghor: Fransa-Senegal Hattında Denge Siyaseti}

Senghor'un Afrikalı öznenin yaşamına dair geliştirdiği varoluşsal ve epistemolojik öngörüler, İkinci Dünya Savaşı'nın başlamasıyla birlikte bir eksen kayması yaşamıştır. Bu süreçte Fransa'da yaşadığı tecrübeler Senghor açısından belirleyici olmuştur. Eğitim amacıyla Fransa'ya gelen Senghor, bu süreci tamamladıktan sonra hayatını Fransa'da devam ettirmeye karar vermişti. Fransız vatandaşı olarak askerlik görevini yerine getirdikten sonra, İkinci
Dünya Savaşı sırasında tekrardan Fransız ordusuna çağrıldı. 1939 yılında ise Alman askerleri tarafindan yakalanması sonucunda Nazi hapishanelerinde 18 aylık bir esaret süreci geçirdi. Bu süre zarfında Senghor, çeşitli şiirler kaleme almış ve bu şiirleri "Siyahi Misafirler" adlı bir kitapta toplamıştı. Yazdığı şiirlerde, Senegalli askerlerin Fransa Cumhuriyeti için canlarını vermelerinin ulvi bir amaç uğruna olduğunu vurgulayan Senghor, Fransa ve Afrika sömürgelerini barış ve kardeşliği esas alan düzlemde birleştirme düşüncesinin işaretlerini vermişi (Lamola, 2016: 57; Kamala, 23-24).

$\mathrm{Bu}$ düşüncenin şekillenmesinde esaret süreci kadar, İkinci Dünya Savaşı'nda ırk üstünlüğü adına yapılan katliamlar da belirleyici olmuştur. Nazilerin uygulamalarında zirveye ulaşan ırkçılığın ne denli korkunç sonuçlar doğurabileceğini müşahede eden Senghor, Siyahi Afrikalıya özgü bir medeniyet fikri ortaya koymak yerine, ırkların üzerine çıkan, evrensel bir değerler sistemi oluşturma fikrini savunmaya başlamıştır (Vaillant, 1976: 156). Bakış açısını ortaya koyarken "kültürel alaşım" kavramından yararlanan Senghor, kültür ve medeniyetlerin birbirleriyle etkileşim içinde oldukları bir idealin başarılmasını savunmuştur (Mabana, 2014: 5).

Senghor'un kültürel kapsayıcılık olarak tanımlanabilecek bir minvalde geçirdiği dönüşümde, Fransız şair Rene Maran (1887-1960) önemli bir etkiye sahip olmuştur. Senghor'dan farklı olarak Maran, iki farklı kültür arasında gelgitler yaşamamış ve siyahi bir Fransız entelektüeli olarak hayatını sürdürmüştür. $\mathrm{Bu}$ duruma rağmen Senghor, Maran'ın şiirlerinde kullandığı dil ve teknikte siyahi bireye has özelikler olduğunu fark etmiştir. İki farklı dünyaya da hitap eden bir entelektüel olarak kültürel alaşım için Maran'ın önemli bir örnek olduğuna kanaat getiren Senghor, bu şairin niçin müstesna bir figür olduğunu şu şekilde açıklamıştır: Maran 'Fransızca konuşan dünyada 'Fransız Yazar' veya 'Siyahi Adam' seçimi ile karşı karşıya bırakılan ilk kişi olmuştu. Ahlaki ve entelektüel dürüstlügün gereği olarak seçim yapmayı reddetti ve aynı anda her ikisi de olma sorumluluğunu üstlendi" (Fabre, 2005: 922, 929-930). Maran'ın şahsında tecessüm ettiği gibi, kültürel sentezi mümkün kılan sömürge tecrübesi, Senghor'un ifadesiyle, etkin bir asimilasyonu beraberinde getirmiş ve böylece verimli bir birlikteliğin zeminini hazırlamıştır (Fabre, 2005: 930-931).

Siyasi ve kültürel olarak Fransa'ya yakın bir çizgi izlemeye başlayan Senghor'un İkinci Dünya Savaşı sonrası edindiği yeni kimlik, kendisini Post-Kolonyalizm dâhilinde farklı bir noktaya taşımıştır. Fransa'nın sömürge geçmişini güçlü sorgulamalara tabi tutma ve sömürge acısını siyahi Afrikalının var oluşunu tanımlayan onto-epistemolojik bir tecrübe olarak görme eğilimi bir tarafa bırakılmıştır. Bunun yerine, Fransa'nın affedildiği ve dünyanın bütün insanlarının nefretten arınmış olarak, evrensel medeniyetin birer mensubu oldukları bir düşünce öne çıkmıştır (Mabana, 2014: 5). Öte yandan Senghor affetmenin Tanrı'ya mahsus bir eylem olduğunu da hatırlatarak, esas itibariyle kendi insanlarını yerinden yurdundan ederek köleleştiren "Beyaz Avrupa" için Tanrı'dan af dilemiştir (Kamara, 28). Senghor'un bu dönemini geçmiş yerine geleceğe odaklanmak olarak tanımlamak mümkündür. Barışçıl bir gelecek inşa etmenin yolunun ise Fransa ve Batı Afrika'nın bir arada kalmasını sağlamak olduğu düşünülmüştür. Bu bakış açısından hareketle Senghor, ülkesi Senegal, Moritanya, Fransız Sudanı, Fransız Gine'si, Fildişi Sahili, 
Yukarı Volta, Dahomey ve Nijer'den oluşan Fransız Batı Afrika'sını, Fransa ile yeni bir siyasi ve kültürel havzada birleştirmeyi amaç edinmiştir.

Benimsediği yeni siyasi yaklaşımla Senghor'un, tam bağımsızlığı şiar edinen Afrika liderlerinin bir bölümünden ayrıştığı önemli bir nokta olarak kaydedilmelidir (Mazrui, 2004: 75). Örneğin, 1945 yılında Manchester'da gerçekleştirilen Pan-Afrika Kongresi'nde sömürge dönemini geride burakmak ve sosyal, ekonomik ve siyasal olarak tam bağımsızlık elde etmek başlıca hedefler olarak zikredilmiştir. Ayrıca "Sömürge Güçlerine Karşı Mücadele" adlı deklarasyonda, son çare olarak güç kullanımına başvurulması çağrısında bulunulmuştur. Kongreye katılan isimlerden, Kenya ve Gana'nın ilk devlet başkanları olarak görev yapacak olan Jomo Kenyatta ve Kwame Nkrumah, Pan-Afrika Kongresi'nin bitişinin hemen ardından bağımsızlık mücadelesine girişmişlerdir. Örneğin Nkrumah, Birleşik Batı Afrika adlı bir devletin kurulması amacına matuf kitleleri harekete geçirmek için oluşturulan Batı Afrika Ulusal Sekreteryası'nın kurucularından biri olmuştur. İkinci Dünya Savaşı sonrasındaki zaman diliminde Senghor ise, Fransa'da aktif bir siyasi figür olarak görev almış ve Dördüncü Cumhuriyet sirasında yeni anayasasının hazırlanması sürecinin içinde yer almıştır (Duffield, 2008: 101-103). Savaşın ardından Senghor, önce SenegalMoritanya bölgesini temsilen, daha sonra ise bağımsız olarak Fransa Ulusal Meclisi'ne milletvekili olarak seçilmiş ve bu zaman zarfinda Edgar Faure hükümetinde (1955-1956) başbakan yardımcı olarak görev yapmıştır (Presidency of Senegal).

$\mathrm{Bu}$ geliş̧melerin Senghor'u Post-Kolonyalizm dahilinde tartışmalı bir figür kıldığı açıktır. Zira Fransa'ya yakın durarak Senghor, sömürge geçmişini sorgulayan düşünce adamı profilinden farklı bir noktaya evirildiğinin işaretlerini vermiştir. Buna rağmen, Fransa'daki siyasi tecrübesinden hareketle Senghor'un diğer Afrika liderlerinden daha düşük bir ulusal bilince sahip olduğunu düşünmek hatalı bir yaklaşım olacaktır. Esas olarak Senghor, Senegal'in ve diğer Batı Afrika uluslarının ulusal egemenlik kavramını katı bir şekilde yorumlamasının hata olacağını düşünmüştür. $\mathrm{Bu}$ nedenle Fransız anayasanın hazırlanması sürecinin içinde yer alarak, bunun kapsayıcı ve Afro-Fransa ulusları arasında "post-emperyal ve post-nasyonal bir federasyonu" mümkün kılacak bir metin olmasına çalışmıştır (Wilder, 2015a). Özü itibariyle, Afrikalıların da yararına olacak şekilde "ulusüstü” bir tahayyül Senghor'un düşüncesine yön vermiştir. Sergilediği çabalara paralel olarak Senghor, Batı Afrikalıların yalnız kendi topraklarını değil, Fransa'yı da yurt olarak görmeleri ve bu yurdun Afro-Fransa şeklinde bir entite olması gerektiğini savunmuştur. Bu bağlamda, Fransa ve eski sömürgelerin ayrı ulus devletler halinde uluslararası sistemde yer almalarındansa, yeni bir siyasi birlik etrafinda bir arada olmaları fikri savunulmuştur (Wilder, 2015b: 5963).

Kendi ülkesi olan Senegal özelinde yaşanan gelişmeler bir süre Senghor'un istediği eksende ilerlemiştir. Senegal'i St. Louis, Gorée, Dakar ve Rufisque'den oluşan "Dörtlü Komün" sistemiyle yöneten Fransa, Senghor gibi Fransız ekolüne göre yetişmiş entelektüellerden komünlerin idaresinde yararlanmayı planlamıştır. Bu süreçte Fransa'nın uyguladığı idari sistem gereği, beyaz ya da siyahi olsunlar, bütün komün mensupları Fransız vatandaşı sayılmışlar ve Fransa'nın hukuk sistemine tabi olmuşlardır. Ayrıca, 1945 sonrası dönemde sömürgelerdeki yerel yönetimlere daha fazla yetki veren Paris, yerel nüfusun Fransa Parlamentosu'na temsilci göndermesinin önünü açmıştır. Bu reformlar Senegal'de yerel siyasi aktörler arasındaki rekabeti kızıştırmış ve Senghor, aşiret liderlerinin ve kırsal bölge insanlarının desteğini elde etmeye çalışarak, gerek bölgesel gerekse ulusal düzeyde öne çıkmaya gayret etmiştir. Ağırlıklı olarak Müslümanların yaşadığı bir ülkede Katolik Hristiyan olan ve baskın etnik grup olan Wolof yerine Serer entisitesinden gelen Senghor, azınlık mensubu biri olarak, farklı etno-dinsel grupların desteğini kazanmaya çalışmıştır (Morgenthau, 2008: 617, 632-633).

$\mathrm{Bu}$ süreçte İslami değerlere saygı duyulacağı, Senegal ekonomisinin kalkındırılacağı gibi bir dizi önemli vaatte bulunan Senghor, ekonomik ve demokratik reformların Fransa Birliği çatısı altında gerçekleşeceğini vurgulamıştır. Böylece Fransa'ya yakın çizgisini sürdürmüştür. Siyasi alanda sergilenen çabalar meyve vermiş ve Senghor'un içinde yer aldığı Senegal Popüler Blok'u 1957 yılındaki seçimlerden galip ayrılmıştır. Fakat 1958 Anayasa Krizi sırasında Fransa Devlet Başkanı Charles De Gaulle'ün Fransız Batı Afrikası'nı tam bağımsızlık ve sınırlı siyasi otonomi arasında bir seçimle karşı karşıya bırakması sonucunda Senegal siyaseti yeni bir yola girmiştir. Her ne kadar Senghor bağımsızlık karşıtı kampanyanın en güçlü isimlerinden biri olmuşsa da 1958 yılında Fransız Birliği’nin yerini alan Fransız Topluluğu'nun dağılması sonucunda Fransa, Afrika devletlerinin bağımsızlıklarını tanımayı kabul etmiştir. Senghor son bir hamleyle Fransız Sudanı ve Senegal'den oluşan Mali Federasyonu adlı yeni bir birlik kurarak Fransa'dan siyasi ve ekonomik anlamda kopmayı önlemeye çalışmışsa da Fransız Sudan'ındaki siyasi aktörlerin kendi otoritesini sarsabilecekleri endişesiyle bu fikirden vazgeçmiştir. Nihai kertede, 20 Ağustos 1960'da Senegal bağımsızlığını elde etmiştir (Detaylar için bkz; Boone, 1992: 80-90; Morgenthau, 2008: 633-636).

Felsefi-poetik duruşuyla Post-Kolonyal ekol dâhilinde önemli bir figür olan Senghor'un ülkesi Senegal'in bağımsızlığına karşı çıkacak derecede geçirdiği keskin dönüşüm, ilgiye mazhar olması gereken bir konudur. Egemenliğin katı bir şekilde tanımlamasının Batı Afrika'ya fayda getirmeyeceğini düşünen Senghor, bunun, Osmanlı İmparatorluğu'nun yaşadığı tecrübeye atıfla, "balkanlaşma" olarak tanımlanabilecek bir sona evrileceğini öngörmüştür (Neuberger, 1976; Chafer, 2002: Chapter 6). Senghor'un merceğinden bakılarak Batı Afrika özelinde karşılaşılacak olası tablo şu şekilde özetlenebilir: etno-dinsel temelde yaşanacak bir devletleşme süreci, kendi başına ayakta kalması zor siyasi oluşumlar ortaya çıkaracaktır. Böylece bağımsızlık kâğıt üzerinde kalacak ve eski emperyal güçlere bağımlılık farklı yöntemlerle de olsa devam edecektir. Ekpo'ya göre, Afrika'nın ekonomik sorunlarını göz önünde bulunduran Senghor, Fransa ile "neokolonyal" bir ilişkinin kaçınılmaz olduğunu düşünmüştür (Ekpo, 2010: 237). Bu ve benzeri sebeplerle Senghor, Senegal'in de içinde yer aldığ Fransız Batı Afrikası adlı birliğin dağılmasına karşı çıkmıştır. $\mathrm{Bu}$ birliğin ileri bir tarihte tekrardan canlandırılmasını imkanız hale getireceği için De Gaulle'ün referandum teklifine olumsuz yaklaşmıştır (Neuberger, 1976: 524).

Senghor'un ekonomik, siyasi ve idari gerekçelerle Afrika'nın hızlı bir devletleşme süreci içine girmesine karşı çıkması ilk anda tartışmalı görülmektedir. Fakat zamanın 
gerçekleri göz önüne alındığında, güçlü itirazları törpülemek mümkündür. Gerçekten de İkinci Dünya Savaşı sonrası dönemde sömürge ülkeleri bağımsızlıklarını kazanmışlarsa da ekonomik kalkınma alanında Batılı güçlere bağımlı kalmaya devam etmişlerdir. Böylece, neokolonyal yöntemlerle merkez ve çeper arasında hiyerarşik ilişkiler sürmüştür (Wallerstein, 1979; Young, 2016; Wilder, 2015b). Gerektiğinde bu ilişkiler askeri darbelerle hâkim kılınmıştır (Westad, 2007: 137-140). Böylece Afrika ülkeleri bağımsızlıklarını kazanmışlarsa da muhtelif yöntemlerle Batılı güçlerin müdahalelerine maruz kalmaya devam etmişlerdir. Bu hususlar bir bütünlük içinde ele alındığında Senghor'un, Afrika halklarının çıkarına olacak şekilde, bir "Afro-Fransa Birliğì" tesis etme çabalarını anlamlandırmak mümkündür. Senghor'u Fransa-Senegal hattındaki siyasi serüveni üzerinden sınamaya tabi tutmak yerine, uluslararası ortamda yaşanan gelişmelere karşı aldığı tavır üzerinden değerlendirmek daha net bir resim sunacaktır.

\section{Uluslararası Arenada Senghor: Gelgitler Arasında İzlenen Dış Politika}

1960-1980 yılları arasında bağımsız Senegal'in devlet başkanı olarak görev yapan Senghor, bu süre zarfında uluslararası gelişmelere dönük aldığ tartışmalara neden olmuştur. İkinci Dünya Savaşı sürecinden itibaren siyasi olarak Fransa'ya yakın bir çizgi izlemeye başlayan Senghor, dünya siyasetini ilgilendiren bazı konularda da bu eğilimini sürdürmüştür. $\mathrm{Bu}$ konuların başında, Cezayir'in bağımsızlığı konusunda alınan tavır gelmiştir. Senghor'un başında olduğu Senegal'in, Birleşmiş Milletler'de Cezayir'in bağımsızlığının ele alındığı oylamalarda çekimser bir tavır sergilemesi tartışmalı konuların başında gelmiştir. Birleşmiş Milleler Genel Kurulu'nda Cezayir'in bağımsızlık hakkının oylandığı 20 Aralık 1960 tarihli bir oturumda 63/8 oranında olumlu oy kullanılırken, Senegal çekimser oy kullanan 27 ülke arasında yer almıştır (United Nations, 1960). Aynı oturumda, eski birer Fransız sömürgesi olan Fildişi Sahili ve Madagaskar'ın olumsuz yönde oy kullandıkları göz önüne alındığında, Senegal'in çekimser yönde oy kullanma tercihini daha esnek bir bağlamda değerlendirmek mümkün görünebilir. Öte yandan Senegal Devlet Başkanı Senghor'un yalnız bir siyasetçi değil, aynı zamanda Afrika felsefesi ve Afrika kültürünün müstesna bir temsilcisi olduğu hatırlandığında, eleştirilerin törpülenmesi güçleşmektedir. Nitekim Senghor'un Cezayir meselesine dönük tavrını eleştiren Fanon tam olarak bu hususa dikkat çekmiştir:

“Afrika Kültür Derneği üyesi olan ve bizimle Afrika kültürü konusunda çalışmış olan Senghor, heyetine Cezayir'deki Fransız politikasının desteklenmesi talimatını vermekten sakınmadı. 'Zenci-Afrika' kültürünü ve Afrika'nın kültürel bütünlüğünü desteklemek, öncelikle insanların kurtuluş mücadelesine koşulsuz destek vermekten geçmektedir" (Fanon, 2004: 170).

1950’lerde Fanon ve Senghor, Afrika insanının karşılaştığı 1rkçılık, kölelik ve tahakküm gibi uygulamaların sonuçları bağlamında benzer noktalara dikkat çekmişlerse de (Senghor, 1956; Fanon, 1956) Fanon'un merceğinden bakıldığında, müteakip dönemde Senghor'un siyasetçi olarak uygulamaları tam manasıyla bir tutarsızlığa işaret etmiştir (Fanon, 2004: 170).
Güney Afrika'daki ırkçı rejime karşı mücadele verirken Nelson Mandela'nın Senghor'dan istediği desteği elde edememesi, mevcut tartışma bağlamında verilebilecek bir diğer örnektir. Senghor ile yaptığı bir görüşmeyi kitabında anlatan Mandela, Senegalli askerlerin Cezayir'de Fransızların safinda görev yaptıkları ve Senghor'un Fransa'ya aşırı yakın olduğu gibi duyumlar aldığını, kaleme aldığı satırlarda dile getirmektedir. Buna ilave olarak Senegal'de bulunduğu ortamlarda kamu görevlisi olarak çalışan Fransızların yoğun mevcudiyetinden endişe duyan Mandela, Fransız varlığının güçlü olduğu bir ortamda Senegal'in Güney Afrika direniş hareketine ne kadar destek sunabileceği konusunda tereddütler yaşamıştır. Nitekim bu tereddütler bir gerçeklik kazanmış ve Mandela'nın Senegal'den askeri eğitim desteği ve mali yardım taleplerini Senghor yerine getirmemiştir. Mandela'ya Parlamento toplanmadan bir karar alınamayacağı gerekçesi sunulmuş ve Mandela ve ekibine diplomatik pasaport temin etmekle yetinilmiştir (Mandela, 1994: 5054-5069; Lamola, 2016: 52).

Üçüncü dünyada meydana gelen farklı olaylar nedeniyle de Senghor eleştirilerin odağında yer almıştır. Sömürge karşıtlığı, siyasi bağımsızlık adına sergilenen çabalar ve Batı eliyle gerçekleştirilen iktidar değişiklikleri gibi olaylara Senghor'un başında olduğu Senegal'in yeterli tepkiyi vermemesi, dile getirilen tenkitler arasında yer almıştır. Spesifik bir örneğe bakıldığında, Senghor'un eleştirildiği başlıca konulardan biri, 1966'da Batı destekli bir askeri darbe sonrası Gana Devlet Başkanı Kwame Nkrumah'nın iktidardan indirilmesine sessiz kalmasıdır. Bu sessizlik, Afrika sathında Kazablanka-Monrovia ihtilafi olarak bilinen, daha derin bir çatlağa işaret etmiştir. Gana, Fas, Cezayir ve Mısır gibi ülkelileri içinde barındıran Kazablanka grubu, Afrika'yı özgürleştirmek ve bütünleştirmek için silahlı mücadele yöntemleri ve Marksist-Leninist bir siyasi program benimsemiştir. Buna karşın Senegal, Fildişi Sahili ve Kamerun gibi ülkeleri bünyesinde bulunduran Monrovia grubu, Batı ile ekonomik ilişkilerin muhafaza edilmesi ve Post-Kolonyal dönemde daha ihtiyatlı bir dış politika izlenmesini savunmuştur (Ratcliff, 2014: 172-173).

Cezayir, Güney Afrika ve Gana gibi hadiselerde Senghor, Fransa'nın önemli bir bileşeni olduğu Batı bloğu ile bir karşıtlık içine girmek istememiştir. Zira Senegal yönetiminin üzerindeki güçlü Fransız etkisi, Senghor'u temkinli davranmaya mecbur bırakmıştır. $\mathrm{Bu}$ husus, ekonomik ve güvenlik eksenli konularda belirgin bir şekilde görülmüştür. Senegal'in kalkınması için Fransa'yı önemli bir partner olarak gören Senghor, Fransız iş çevrelerinin ekonomi yönetiminde etkili konumda olan Senegalli yetkililerle güçlü temas halinde olmasını sağlamıştır. Senegal'de sanayi, bankacılık ve ticaret alanında patron ve yönetici sınıfındaki Fransızlar, yalnızca Senghor ve bakanlarla güçlü ilişkiler kurmakla kalmamış, danışmanlık organları ve planlama komisyonlarında temsil hakkı da elde etmişlerdir. Ekonomik olduğu kadar güvenlik alanında da Senegal üzerinde Fransız etkisi hissedilmiştir. Senegal devlet başkanlığı çevresinde Fransız birlikleri konuşlandırılarak, Senghor'un koruması sağlanmıştır. Böylece Afrika'da askeri darbe ve toplumsal kalkışma gibi eylemlerle devlet başkanlarının görevden indirilebildiği göz önüne alınarak, Fransa'nın desteğiyle Senghor'un benzer bir akıbetten uzak tutulmasina çalışılmıştır. Nitekim Fransız birlikleri, 1959-60'da Mali Federasyonu'nun dağılmasında, 1962'deki anayasa krizi 
sırasında, 1963 'te şiddete sahne olan seçimlerde ve 19681970 yıllarındaki toplumsal gerginlikler sirasında görev alarak, Senghor'un korumasını üstlenmişlerdir (Boone, 1992: 100-101).

Gerek Fransa-Senegal ilişkilerini, gerekse Senegal'in farklı uluslararası meselelere yönelik yaklaşımını analiz ederken, Soğuk Savaş koşullarının göz önünde bulundurulması önem arz etmektedir. Soğuk Savaş döneminde yaşanan gelişmeler, Batı bloğunda yer alan Fransa'ya doğrudan tesir ederken, Fransa üzerinden Soğuk Savaş'ın etkileri Senegal'e de sirayet etmiştir. Örneğin Cezayir'de geçici yönetimde görev alan Dışişleri Bakanı Belkacem Krim, Fransa'nın Cezayir üzerindeki baskısının azaltılması için Kamerun ve Senegal gibi ülkelerdeki Fransız karşıtı radikal aktörlere silah desteği sunulması çağrısında bulunmuştur (Evans, 2012: 289). Böylece Fransa'ya yakın olduğu düşünülen Senghor iktidarına bir tehdit yöneltilerek, Fransa'nın dizginlenmesine çalışılmıştır. Bu gibi risklerin farkında olan Senghor, izlediği dış politikayla gerek bölgesel gerekse uluslararası düzeyde hassas bir denge tutturmaya çalışmıştır. Diagne'nin vurguladığı gibi, Kenyatta, Nkrumah, Bourguiba ve Lumumba gibi liderlerden farklı olarak Senghor, üzerinde sömürgeciliğin etkisi bulunan bir ülkeyi Soğuk Savaş sürecinde ustalıkla yönetebilmiştir (Diagne, 2002: 12-13).

$\mathrm{Bu}$ tartışma bağlamında şu husus vurgulanmalıdır ki, 19571962 arasındaki yalnızca beş yıllık dönemde 25 Afrika ülkesinin bağımsızlığına kavuşması, Afrika kıtasını Soğuk Savaş rekabetinin etki alanına sokmuştur. Post-Kolonyal dönemdeki hızlı bağımsızlık süreci, yeni elit kadroların iktidara gelmesini sağlarken, ABD ve Sovyetler Birliği bu kadrolar üzerinde etki kurarak müttefik ülkeler kazanmanın gayretinde olmuştur (Westad, 2007: 90-91). Böylece büyük güçler, Üçüncü Dünya'da birbirlerine alan kaptırmamaya azami önem vermișlerdir. Örneğin 1960'lardan itibaren Afrika'daki mevcudiyetini güçlendiren Sovyetler Birliği; Kongo, Cezayir ve Gana gibi ülkelerle yakın ilişki içindeyken, 1960-1966 arasında bu üç ülkede gerçekleşen askeri darbeler sonucunda ABD'ye alan kaptırmıştır (Westad, 2007: 159).

Öte yandan Senghor gibi Pan-Afrikanizm hareketinin önemli isimlerinden biri olan Portekiz Gine'si Devlet Başkanı Amilcar Cabral'ın 1980'de bir darbe ile indirilmesi, farklı siyasi oryantasyona sahip liderlerin de darbe tehdidinden azade olmadığını göstermiştir. Darbeden sonra Sovyetler Birliği yeni yönetimi hemen tanıma, ABD ise dış yardım miktarını arttırma kararları alarak, yeni rejimi yanlarına çekmeye çalışmışlardır (Munslow, 1981). Soğuk Savaş’ın güçlü rekabet ortamında darbe veya isyan yoluyla görevden uzaklaştırılma riski Senghor için de söz konusu olmuştur. Belirli dönemlerde ordu içinde meydana gelebilecek sol tandanslı bir cunta hareketlenmesi ihtimali Senghor'u tedirgin etmiş ve bu gibi durumlarda Fransa'nın desteği Senghor'un yanında olmuştur. Senegal ordusu içinde danışman/teknik asistan olarak görev yapan Fransız askerler, isyana yatkın Senegalli askerleri dizginleyerek, Fransa'nın Senghor'un liderliğindeki siyasi düzenin arkasında olduğunu aktarmışlardır (Boone, 1992: 101).

Senghor'un Soğuk Savaş koşulları altında Senegal'in dış politika uygulamalarına yön veren tercihleri, kendisini ne Üçüncü Dünya'daki gelişmelere sırt çeviren ne de Afrika'nın geçmişte yaşadığı sorunlarla ilgilenmeyi bırakan bir figür haline getirmiştir. Post-Kolonyal dönemde Senegal Devlet
Başkanı olarak görev yapan Senghor, mağduriyet yaşayan halkların sorunlarına hassasiyet göstermeyi sürdürmüştür. $\mathrm{Bu}$ sorunların arasında, Batı Timor halkının yaşadığı mağduriyet gelmiştir. Endonezya'nın Doğu Timor'u ilhak etme çabalarına Henry Kissinger vasıtasıyla ABD yeşil 1 şık yakmış ve Doğu-Batı blokları ve Üçüncü Dünya tam bir kayıtsızlık sergilemişse de Senghor, Doğu Timor sorununa eğilen yegâne Afrika lideri olarak tebarüz etmiştir. Doğu Timor halkının self-determinasyon hakkını savunan Senghor, Timorluların siyasi mücadelelerini yürütebilmeleri için Dakar'da örgütlenmelerinin önünü açmış ve bu doğrultuda mali ve organizasyonel destekte bulunmuştur. Ayrıca Senegal, Doğu Timor direniş hareketini meşru bir siyasi aktör olarak tanıyan ilk Afrika devleti olmuştur (Soyinka, 2002).

Senghor'un Senegal'den çok uzak bir bölge olan Doğu Timor'a ilgi göstermesi, esas itibariyle Siyahi ırkın Hindistan, Papua Yeni Gine ve Güney Denizi Adaları'na kadar uzanan bir coğrafyadaki varlığına gösterdiği hassasiyetin bir sonucudur (Soyinka, 2002). Bu hassasiyetin merkezinde ise kendi toprağı olan Afrika kıtası yer almıştır. Devlet Başkanı olarak bulunduğu ortamlarda Senghor, Afrikalıların sömürge döneminde yaşadı̆̆ı eziyeti çarpıcı ifadelerle hatırlatmaya devam etmiştir. 1974 senesinde yaptığı bir konuşmada, 350 yıl devam eden köle ticareti ve insan avcılığı sonucunda 200 milyon Afrikalının yok olduğunu hatırlatan Senghor, bu hadisenin tarihteki en büyük soykırım olduğunu belirtmiştir. Senghor'a göre, yaşanan insani ve kültürel kayıp Afrika'nın geri kalmışlığının temel nedeni olup, sömürge tecrübesi yüzünden Afrika'nın enerjisi ve yaratıcı gücü tahrip edilmiştir (Senghor, 1974: 32).

Senhor'un bu ifadeleri 1956 yılında kaleme aldığ makalede ortaya koyduğu güçlü sorgulamaları tamamlar niteliktedir. Söz konusu makalede Senghor, Avrupa Rönesans'ının siyahi Afrika uygarlığının kalıntıları üzerine inşa edildiğini, Amerika'nın ise "zenci kanı ve teri" sayesinde mevcut gücüne ulaştığını vurgulamıştır (Senghor, 1956: 51). Afrika kıtasının gelişmişlik ve etno-dinsel ayrımcılık gibi sorunlarla başa çıkmak zorunda olduğunun farkında olan Senghor, geçmişte yaşanan eziyetleri unutmasa da, Post-Kolonyal dönemde ilerlemenin makul bir düzlemde olabileceğine inanmıştır. Bunun için Avrupa'da savaşlarla tecrübe edilen "mikro-milliyetçilik" hadisesine atıf yaparak, etno-kültürel fanatizmin tuzağına düşülmemesi ve farklılıkların, evrensel medeniyete de katkı sunacak şekilde, Afrika'nın zenginliği olduğunun unutulmaması gerektiğini vurgulamıştır (Senghor, 2013: 85-86). Gerekli anlarda kendisini de dahil ederek özeleştiriler dile getiren Senghor, Güney Afrika ve Portekiz sömürgeciliğine dair eylemden çok laf üretildiğini ve artık ekonomik ve diplomatik yaptırımların sistematik bir şekilde uygulanması gerektiğini aktarmıştır (Senghor, 2013: 87).

Bütün bu hususlar, Post-Kolonyal ekol dâhilinde Senghor'un niçin üzerinde uzlaşılması zor bir isim olduğu konusunda önemli ipuçları sunmaktadır. Siyasetçi ve düşünce insanı olarak kariyerinin belirli anlarında Afrika medeniyetinin güçlü savunusunu yapan Senghor, belirli anlarda daha pragmatik bir çizgi izlemiştir. Son tahlilde, siyaset alanında Senghor, Post-Kolonyal dönemde ve Soğuk Savaş koşulları altında kaçınılmaz olarak reelpolitik ögelere siyasetinde yer vermiştir. Petrol ve değerli mineral gibi doğal kaynaklara sahip olmayan Senegal'in ayakta kalabilmesi için Batı'dan gelen yatırımın öneminin farkında olan Senghor, bu nedenle 
dengeli bir dış politika yürütmeyi zaruri görmüştür. İzlenen dış politikanın temel amacı Senegal'i istikrarsızlıklardan uzak tutmak olmuştur. Nitekim 1980 yılında görevinden ayrılarak Afrika'da gönüllü bir şekilde başkanlığı devreden ilk kişi olan Senghor, Afrika kıtasında sıkça görülmüş olan kaos ve şiddetten Senegal'i görev süresi zarfında uzak tutarak, kendisinden sonraki yönetimlere görece barışçıl bir ülke teslim edebilmiştir (Vaillant, 2002: 21).

\section{Sonuç}

Léopold Sédar Senghor, 20. yüzyıl düşünce tarihine Afrika kıtasından 1şık tutan bir figürdür. Senghor siyaset sahnesine çıktığında, düşünce adamı kimliği ile çelişen bazı kararlara imza atmışsa da bunlar, önemli ölçüde, zamanın özgül koşulları ve önündeki siyasi sorumlulukların kendisinin hareket alanını daraltması nedeniyle olmuştur. Gerçekten de Post-Kolonyal dönemde Afrika'nın hızlı bir bağımsızlık ve devletleşme sürecine girmesinin tehlikelere kapı aralayabileceği yaşanan etnik ve mezhepsel çatışmalarla görülmüştür. Nitekim Senghor da etno-dinsel temelde meydana gelebilecek çatışma riskine dikkat çekerek, İkinci Dünya Savaş sonrası dönemde temkinli bir yol izlemenin gerektiğini düşünmüştür. Ekonomik kalkınma bağlamında ise Afrika'nın eksikliklerinin farkında olan Senghor, başta Fransa'dan olmak üzere, dış yatırımı ülkesine çekmek suretiyle Senegal'in gelişmesini tamamlayabileceğine kanaat getirmiştir. Bunun için ülkesinin dış politika oryantasyonunu belirlerken, Fransa/Batı karşıtı bir çizgi izlemekten imtina etmiştir.

Senghor'un siyasi ve felsefi serüveni Post-Kolonyalizm dahilinde niçin konjonktürel bir okuma yapmanın gerekli olduğunu bize göstermektedir. Totalist yaklaşımlarla, doğruyanlış dikotomisi üzerinden olaylara bakmanın, istenen açıklıkta olayları anlamanın önüne engel çıkaracağı kaydedilmelidir. Senghor gibi bir düşünürü anlama ve açıklama denemesinde, zamanın şartlarının dikkate alınması, düşünce insanı, entelektüel, siyasetçi, devlet adamı gibi edinilen yeni kimlikler etrafinda yeni okumaların yapılması zaruridir. Nitekim unutulmamalıdır ki Post-Kolonyalizm' in merkezi öznelerinden biri olan Fanon da Fransız ordusunda görev yapmış bir isimdir; sonraki aşamada geçirdiği dönüşümle ise Fanon, Üçüncü Dünya halklarının Fransa'dan bağımsızlı̆̆ını kazanma davasının en güçlü savunucularından biri olmuştur. Senghor da uzun yaşamı boyunca önemli bir dönüşüm geçirmiştir. Fakat bu dönüşüm, Fanon'dan farklı olarak, Üçüncü Dünya'dan Fransa'ya doğru bir çizgide ilerlemiştir. Öte yandan, bu dönüşümden hareketle Senghor'a dönük tenkit içerikli bir yaklaşım ortaya koymak hatalı olacaktır.

$\mathrm{Bu}$ çalışmada vurgulandığı gibi, dekolonizasyon ve Soğuk Savaş koşulları sırasında görev yapan Senghor, siyasi uygulamalarını hassas bir denge üzerinde icra etmek zorunda kalmıştır. Bunun için, önceki dönemde geliştirdiği felsefipoetik bakış açısına tezat eylem ve söylemlere imza atmıştır. Beyaz Avrupa'nın sömürge dönemindeki günahları için Tanrı'dan af dilemesi ve Batı Afrika'nın Fransa'dan kopmasının istememesi, bu tezatlığın net bir şekilde görülmesi için yeterlidir. Tartışmalı taraflarına rağmen Senghor, Cesaire ile birlikte, Post-Kolonyal ekol içinde kilit bir düşünür olma özelliğini korumaktadır. Zira özgürlük mücadelesinin kümülatif bir mücadele olduğu düşünüldüğünde, 1930'lardan itibaren Senghor'un siyahi
Afrikalının özgürleşmesi ve Beyaz Avrupalının hesaba çekilmesi için ortaya koyduğu çabalar, bu geniş mücadelenin bir parçasıdır.

Felsefeci ve şair kimliğinden siyasetçi ve devlet adamı kimliğine geçiş yaptığında Senghor, ister istemez pragmatik bir yol izlemek zorunda kalmıştır. Senghor'un siyasi kariyerine odaklanıldığında şu görülmektedir ki, Afrika'da iç çatışma ve kıtlık gibi sorunlar nedeniyle yaşanan kitlesel yıkımlardan Senegal sakınabilmiştir. Bu husus, Senegal özelinde bir başarı hikâyesine işaret etmektedir. Senegal'in doğal kaynak zengini olmasa da ekonomik darboğaza sürüklenmediği, iktidar değişikliklerini sakin bir şekilde gerçekleştirebildiği ve toplumsal huzursuzlukları görece sakin bir şekilde atlatabildiği hatırlandığında, Senghor'un başarısı net bir şekilde görülebilecektir. Tarihsel-kültürel bağlamda bir değerlendirme yapıldığında ise Senghor'un siyasi kariyerinin ilerleyen dönemlerinde dahi, Batı'nın günahlarını hatırlatmaktan sakınmadığı kaydedilmelidir. Bu bağlamda Senghor, Afrika'nın yaşadığı tarihsel trajedinin insanlık tarihinin en büyük soykırımı olduğu ve bu soykırımın beyaz Avrupalılar tarafından uygulandığını hatırlatmaya devam etmiştir.

Bu hususlar bir araya getirildiğinde bu çalışma, Senghor'un belirli dönemlerde yaşadığg gelgitlere rağmen, düşünce adamı kimliği ile siyasetçi kimliği arasında, çok güçlü olmasa da, belirli paralellikler yakalamaktadır. Her halükarda olumlu ya da eleştirel taraflarıyla Senghor'un, Post-Kolonyal düşünce dâhilinde üzerinde anlaşılması zor olan bir isim olduğu açıktır. Buna rağmen gerek filozof ve şair kimliklerini bünyesinde barındıran gerekse Fransa ve Senegal'in her ikisinde de aktif olarak siyasetle iştigal etmiş olan bu ismin, 20. yüzyıl siyasi düşüncesinin önemli bir temsilcisi olduğu yadsınamaz bir gerçektir.

\section{Kaynakça}

Adib-Moghaddam, A. (2011). A Metahistory of the Clash of Civilisations: Us and Them. Beyond Orientalism. London, Hurst \& Company.

Agada, A. (2018). A Truly African philosophy. (Erişim: 08.09.2020), https://aeon.co/essays/consolationphilosophy-and-the-struggle-of-reason-in-africa

Al-'Azm, S. J. (2000). Orientalism and Orientalism in Reverse. İçinde A. L. Macfie (Ed.), Orientalism: A Reader (217-238). Edinburgh: Edinburgh University Press.

Barkawi, T. (2008). Orientalism, 'Small Wars', and Big Consequences in Korea and Iraq, Arena 29(30). (Erișim:

13.01.2021), https://www.academia.edu/348893/Small_Wars_Big _Consequences_and_Orientalism_Korea_and_Iraq_

Boone, C. (1992). Merchant Capital and the Roots of State Power in Senegal: 1930-1985. Cambridge: Cambridge University Press.

Cesaire, A. (1969). Return to My Native Land. Middlesex, Penguin Books. 
Chafer, T. (2002). The End of Empire in French West Africa: France's Successful Decolonization?. Oxford: Berg Publishers.

Clark, A. F. \& Phillips, L. C. (1994). Historical Dictionary of Senegal African. London: Scarecrow Press.

Darby, P. (2004). Pursuing the Political: A Postcolonial Rethinking of Relations International. Millennium: Journal of International Studies, 33(1), 1-32.

Diagne, P. (2002). Senghor in Context. Research in African Literatures, 33(4), 12-16.

Duffield, I. (2008). Pan-Africanism Since 1940. İçinde M. Crowder (Ed.), The Cambridge History of Africa Volume 8 from c. 1940 to c. 1975 (95-141). Cambridge: Cambridge University Press.

Ekpo, D. (2010). Speak Negritude But Think and Act French: The Foundations of Senghor's Political Philosophy. Third Text, 24(2), 227-239.

Evans, M. (2012). Algeria: France's Undeclared War. New York: Oxford University Press.

Dirlik, A. (1998). The Postcolonial Aura: Third World Criticism in the Age of Global Capitalism Colorado: Westview Press.

Fabre, M. (2005). Rene, Louis, and Leopold: Senghorian Negritude as a Black Humanism. Modern Fiction Studies, 51(4), 921-935.

Fanon, F. (2004). The Wretched of the Earth. Richard Philcox (Çev.). New York: Grove Press.

Fanon, F. (1956). Racism and Culture. Presence AfricaineCultural Journal of the Negro World, 8-9-10, 122131.

France in West Africa. (Erişim: 05.09.2020), https://www.arcgis.com/apps/Cascade/index.html?ap pid=7352494797d94473a5366336f5466fc2

Heidegger, M. (1977). The Question Concerning Technology and Other Essays. William Lovitt (Çev.). New York: Garland Publishing, Inc.

Hobsbawm, E. (1996). The Age of Revolution 1789-1848. New York: Vintage Books.

Horkheimer, M. \& Adorno, T. W. (2002). Dialectic of Enlightenment: Philosophical Fragments. Edmund Jephcott (Çev.). Stanford, Stanford University Press.

Irele, A. (1965). Négritude or Black Cultural Nationalism, The Journal of Modern African Studies, 3(3), 321348.

Jacques, T. C. F. (2011). Philosophy in Black: African Philosophy as a Negritude. Sartre Studies International, 17(1), 1-19.

Jones, D. V. (2010). The Racial Discourses of Life Philosophy: Négritude, Vitalism, and Modernity. New York, Columbia University Press.

Kamara, M, Slavery, Colonialism, Human Rights, and the Négritude of Léopold Sédar Senghor. Enter Text, 7(2), 16-34.
Kras, S. (1999). Senghor's Rise to Power 1948-1951: Early Roots of French Sub-Saharan Decolonisation. Itinerario, 23(1), 91-113.

Krishna, S. (2001). Race, Amnesia, and the Education of International Relations. Alternatives, 26, 401-424.

Laffey, M. \& Weldes, J. (2008). Decolonizing the Cuban Missile Crisis. International Studies Quarterly, 52, 555-577.

Lamola, M. J. (2016). Senghor, Globalism and Africanity. Phronimon, 17(2), 51-67.

Lewis, B. (1982). The Question of Orientalism. New York Review of Books. (24.06.1982). (Erişim: 14.01.2021), https://www.nybooks.com/articles/1982/06/24/thequestion-of-orientalism/

Losurdo, D. (2011). Liberalism: A Counter-History. Gregory Elliott (Çev.). London: Verso.

Mabana, K. C. (2014). Léopold Sédar Senghor and the Civilization of the Universal. Diogenes, 59(3-4), 412.

Mandela, N. (1995). Long Walk to Freedom. Kindle Edition: Boston, Little, Brown \& Company.

Mazrui, A. A. (2004). Power, Politics, and the African Condition: Collected Essays of Ali A. Mazrui. Trenton: Africa World Press, Inc.

Mitchell, T. (2002). McJihad: Islam in the U.S. Global Order, Social Text 20(4), 1-18.

Morgenthau, R. S. (2008). "French-Speaking Tropical Africa", İçinde M. Crowder (Ed.), The Cambridge History of Africa Volume 8 from c. 1940 to c. 1975 (611-673). Cambridge: Cambridge University Press.

Mortimer, M. (2002). Sine and Seine: The Quest for Synthesis in Senghor's Life and Poetry. Research in African Literatures, 33(4), 38-50.

Mortimer, M. (2004). African Literature in French: SubSaharan Africa During the Colonial Period. İçinde S. Gikandi \& A. Irele (Ed.), The Cambridge History of African and Caribbean Literature Volume 1 (530551). Cambridge: Cambridge University Press,

Mortimer, R. A. (1972). From Federalism to Francophonia: Senghor's African Policy. African Studies Review, 15(2), 283-306.

Munslow, B. (1981). The 1980 Coup in Guinea Bissau. Review of African Political Economy, 21, 109-113.

Neuberger, B. (1976). The African Concept of Balkanisation. The Journal of Modern African Studies, 14(3), 523-529.

Okoth, A. (2006). A History of Africa Vol.1: 1800-1914. Nairobi: East African Educational Publishers.

Presidency of Senegal. Léopold Sédar Senghor. (Erişim: 20.09.2020),

http://www.presidence.sn/en/presidency/leopoldsedar-senghor

Ratcliff, A. J. (2014). When Négritude Was in Vogue: Critical Reflections of the First World Festival of 
Negro Arts and Culture in 1966. The Journal of Pan African Studies, 6(7), 167-186.

Rowe, M. (2013). The French Revolution, Napoleon, and Nationalism in Europe. İçinde J. Breuilly (Ed.), The Oxford Handbook of the History of Nationalism (127-148), Oxford: Oxford University Press.

Said, E. (1993). Culture and Imperialism. New York: Vintage Books.

Said, E. W. (2003). Orientalism. London: Penguin Books.

Sartre, J. P. (1988). "What is Literature"' and Other Essays. Massachusetts, Harvard University Press.

Sartre, J. P. (2004). Preface by Jean-Paul Sartre. İçinde The Wretched of the Earth (xliii- 1xii). New York: Grove Press.

Senghor, L. S. (1956). The Spirit of Civilisation, or the Laws of African Negro Culture. Presence AfricaineCultural Journal of the Negro World, 8-9-10, 51-64.

Senghor, L. S. (1974). Speech by Mr. Leopold Sedar Senghor President of the Republic of Senegal. Présence Africaine, 92, 31-38.

Senghor, L. S. (2013). His Excellency Leopold Sedar Senghor, President of the Republic of Senegal, Celebrating Success: Africa's voice over 50 years 1963-2013. (Erișim: 20.09.2020), http://hdl.handle.net/10855/22129.

Sessions, J. E. (2011). By Sword and Plow: France and the Conquest of Algeria. Ithaca: Cornell University.

Skurnik, W. A. E. (1965). Leopold Sedar Senghor and African Socialism. The Journal of Modern African Studies, 3(3), 349-369.

Smith, S. (2000). The Discipline of International Relations: Still an American Social Science?. British Journal of Politics and International Relations, 2(3), 374-402.

Soyinka, W. (2002). Lessons in Power. Research in African Literatures, 33(4), 1-2.

Spivak, G. (2010). Can the Subaltern Speak?: Reflections on the History of an Idea. İçinde R. C. Morris (Ed.), Can the Subaltern Speak?: Reflections on the History of an Idea (21-78). New York: Columbia University Press.

The Editors of Encyclopaedia Britannica. (2019). Léopold Senghor. (19.12.2019). (Erişim: 07.08.2020), https://www.britannica.com/biography/LeopoldSenghor

Thompson, P. S. (2002). Negritude and a New Africa: An Update. Research in African Literatures, 33(4), 143 153.

United Nations. (1960). Question of Algeria: Resolution / Adopted by the General Assembly. (Erişim 05.09.2020), https://digitallibrary.un.org/record/667618?ln=en

Vaillant, J. G. (1976). Review: Perspectives on Leopold Senghor and the Changing Face of Negritude. ASA Review of Books, 2, 154-162.

Vaillant, J. G. (2002). Homage to Léopold Sédar Senghor: 1906-2001. Research in African Literatures, 33(4), 17-24.

Westad, O. A. (2007). The Global Cold War: Third World Interventions and the Making of Our Times. Cambridge: Cambridge University Press.

Wallerstein, I. (1979). The Capitalist World Economy. Cambridge: Cambridge University Press.

Wilder, G. (2005). The French Imperial Nation-State: Negritude \& Colonial Humanism Between Two World Wars. Chicago: The University of Chicago Press.

Wilder, G. (2015a). Apart Together. (Erişim 01.08.2020), https://aeon.co/essays/how-cesaire-and-senghorsaw-the-decolonised-world

Wilder, G. (2015b). Freedom Time: Negritude, Decolonization, and the Future of the World. Durham: Duke University Press.

Young, J. C. R. (2016). Postcolonialism: An Historical Introduction. West Sussex: Blackwell Publishing. 


\section{Extended Absract}

Leopold Sedar Senghor is considered to be one of the pioneering figures of the Post-Colonial thought. As a poet, philosopher, intellectual, scholar and politician, Sengor's life holds a mirror to the Post-Colonial era as a whole. Throughout his long life, Senghor dedicated his intellectual capital to the emancipation of the African subject from the shackles of colonial and imperial domination and practices. Although Senghor is best known for his contribution to Pan-Africanism, his influence is not confined to this area only. As an all-inspiring figure, he has remained an iconic intellectual within the broader Third World, given his fierce denunciation of Western colonial domination. Senghor's influence as an intellectual date back the 1930s, when he participated in the development of the Negritrude movement, along with Aimé Césaire ve Léon Damas. The coming together of these three figures around the same cause of defending the rights of Negro-African subject constitutes early attempts in the development of Post-Colonialism as an intellectual and scholarly activity.

Yet, this process was not without anomalies. As exemplified in the person of Senghor, his intellectual development took place within the confines of the French education system and French was his first language, through which he articulated his anti-colonial feelings in his works. This means that when he set out to make visible historical injustices and the suffering of the Africans in the hands of Western colonists, he had to use the language of those who had colonized his people. Nevertheless, Senghor utilized the medium of language in such an effective way that amounted to weaponizing it, which implies that he challenged and undermined the narratives pertaining to the pre-eminence of the Western civilization through his effective use of French in his works of prose and poetry. In the texts Senghor produced, he also highlighted the African subject's distinctive qualities, with the objective of proving that not only was the African not inferior, but he possessed superior characteristics and these, as he argued, derived from his ability to live in harmony with nature. As opposed to the European subject, whose way of living and thinking was predicated on instrumental rationality, which instilled in him a domination-seeking mentality, the African subject, according to Senghor, had no innate inclination to pursue domination. This is because, he did not make a sharp distinction between himself and his environment and embraced life in its wholeness.

Although Senghor's intellectual undertakings placed him in a unique position within the Post-Colonial thought, as a politician, he presented a profile that was at odds with his earlier identity. Senghor rose to prominence as politician when he was elected as the first president of Senegal, which gained its independence from France in 1962. Even predating his ascendance to presidency, Senghor had been seeking ways to maintain political, economic and cultural links between France and its colonies. In the post-Second World War period, he came to the conclusion that, as practiced by the Nazis, drawing a firm line between races and civilizations was rife with danger, generating the risks of extreme-nationalism, fascism and racism. He first-hand experienced the consequences of extremism in the Second World War, during which he had served in the French army, a process also marked by his imprisonment by the Nazis. This experience led Senghor to reconsider his earlier ideas, ultimately embracing the thought that attempts must be focused on unity rather than divisiveness. And in Senghor's eyes, seeking political economic independence would be a counterproductive move and the right way forward in the post-war period would be to forge a post-imperial political entity, which would encompass France and ex-colonies under the same politicoadministrative system. So, rather than going down the road of rapid disintegration, which Senghor believed would be fraught with risks given the prospect of sectarian tensions, ethnic conflicts and so on, he defended the continuity of French-African ties.
Such views rendered Senghor a controversial figure, because his thought lineage revealed significant inconsistencies. From being one of the champions of anti-colonialism and Pan-Africanism, Senghor moved on to become a political and intellectual figure that argued against African nations' political independence from France. The contentious aspects of Senghor's latter life became all the more apparent in following periods, since he made highly controversial decisions as Senegal's president. Perhaps the most controversial decision was to abstain in the United Nations from voting on Algeria's independence. France Fanon was among those who had criticized Senegal's stance, reminding Senghor how his pro-French behaviour was at odds with his early life. Senghor's refusal to give the required support to Nelson Mandela when the latter was working to end apartheid and his silence on Ghanaian President Kwame Nkrumah's overthrow by a U.S-backed military coup are further examples that cast further shadow on Senghor's legacy.

Having said all this, Senghor's intellectual and political journey and his position within the Post-Colonial thought cannot be properly understood unless different segments of his life are contextualized. Although some of the political decisions made by Senghor were at variance with his intellectual posture, these decisions mostly derived from the conditions in which he had found himself. As president of Senegal, he had before him daunting political, economic and administrative tasks and responsibilities, the fulfilment of which required charting a careful course during the tumultuous times of the Cold War and Post-Colonial period. Senegal, like most African states, was in need of economic help, foreign investment, technical assistance and military support, as the continent was experiencing serious hardships during the PostColonial era, marked by civil wars, military coups, insurrections, famine and poverty. Senghor's policy was best described as one that was based on the goal of keeping Senegal away from economic and social troubles, and he was aware of Senegal's inadequacies to cope with the existing challenges. In order to keep his country afloat, Senghor maintained a close relationship with France, which provided Senegal with economic and military support, when the latter faced hardships and instabilities.

On the intellectual front, Senghor still adhered to his earlier principle of ending all forms domination and subjugation. He was the only Post-Colonial president, for example, to have supported the cause of the East Timorese in their struggle to achieve independence. Senghor's pro-Timorese stance was part of his overall commitment to contribute to the liberation struggle of the black race, regardless of where they were and where they faced subjugation. So, the liberation struggles which Senghor contributed to was unlimited to Africa, and he remained one of the leading defenders of the liberation struggles of the people of the Third World. Last but not least, although Senghor became subject to fierce criticisms on account of his political decisions, it needs to be reminded that Senegal, despite lacking rich natural resources, managed to avoid the economic and social collapse that befell many countries in Africa. Under Senghor, who stepped down as president in 1980, Senegal also qualified as the first African state in which a peaceful transfer of power took place.

Overall, although the tension between Senghor's intellectual and political identities are evident, Senghor unavoidably had to pursue a pragmatic/realist course in governing a Post-Colonial nation. Senghor's political legacy, however, should not lead one to dismiss his intellectual struggles to end colonial domination. As liberation struggles entail a cumulative effort in the form of intellectual or psychical resistance to domination, Senghor retains his special place within the Post-Colonial domain for having contributed to this overall struggle as an intellectual and poet. 